\title{
GIARDIA MURIS AND GIARDIA DUODENALIS GROUPS: ULTRASTRUCTURAL DIFFERENCES BETWEEN THE TROPHOZOITES
}

\author{
Maria Inês L. SOGAYAR (1) \& Elisa Aparecida GREGóRIO (2)
}

\begin{abstract}
SUMMARY
Trophozoites of the Giardia muris group from hamsters, domestic rats and mice and of the Giardia duodenalis group from hamsters and domestic rats were examined by transmission electron microscopy. The basic ultrastructure of the trophozoites was similar. Differences were shown in the morphology of the ventrolateral flange of the trophozoites of Giardia muris and Giardia duodenalis groups. Marginal plates are less developed in the species of the Giardia duodenalis group. In this group, the distal extremity of the lateral flange is short and thick and the marginal plate does not penetrate into the distal extremity of the flange. In the Giardia muris group, the ventro-lateral flange is well developed and narrow and the marginal plate penetrates the distal extremity of the flange. The osmiophilic lamella, which accompanies the dorsal surface of the marginal plate is seen only in the Giardia muris group.
\end{abstract}

KEY WORDS: Giardia muris; Giardia duodenalis; Trophozoite, Ultrastructure.

\section{INTRODUCTION}

Based on the median body morphology and the trophozoite's size and shape one can differentiate Giardia muris and Giardia Juodenalis by light microscopy 4 . The data in the literature about such differentiation by electron microscopy are scarce. NEMANIC et. al. 12 were unable to show differences between trophozoites of Giardia muris from mice and those of Giardia lamblia from man.

Taking in account these results and since the morphology of Giardia from hamsters and domestic rats had not been described yet, we decided to study comparatively the ultrastructure of Giardia muris and Giardia duodenalis trophozoites found in hamsters, domestic rats and mice.

\section{MATERIAL AND METHODS}

Giardia species from naturally infected animals were previously identified by light microscopy. Smears of faeces or mucosa were fixed with Schaudinn's solution and stained with Heidenhain's haematoxylin. The species of Giardia were identified by morphological features and trophozoite length and width measurements, at $1.000 \mathrm{x}$ magnification.

Trophozoites of the Giardia muris group from hamsters, domestic rats (Rattus rattus rattus) and mice and Giardia duodenalis group from hamsters and domestic rats were used. Fragments of the host's mucosa were fixed in $2.5 \%$ glutaraldehyde buffered at pH 7.3 with

(1) Department of Parasitology, IBB, UNESP, 18600 Botucatu, São Paulo, Brazil.

(2) Department of Morphology, IBB, UNESP, 18600 Botucatu, São Paulo, Brazil. 
SOGAYAR, M.I.L. \& GREGORIO, E.A. - Giardia muris and Giardia duodenalis groups: ultrastruetural differences betweell the trophozoites. Rev. Inst. Med. trop. S. Paulo, 31(4):242-247, 1989.

$0.1 \mathrm{M}$ phosphate buffer, posi-fixed in $1 \%$ osmic tetroxide in the same buffer and embedded in Araldite. The ultrathin sections were stained with uranyl acetate and lead citrate and examined with an EM 301 Philips electron microscope.

\section{RESULTS}

The basic ultrastructure of the trophozoites of Giardia inuris group from hamsters, domestic rats and mice and Giardia duodenalis group from hamsters and domestic rats is similar. The trophozoites hate a microtubular adhesive disk surrounded by an adjacent cyloplat mic flange known as the ventro-lateral nange and four pairs of tlagella (Fig. 1) whose basai hodies are located between the two nucies. Onmiophilic material is seen nexi to the axonemes of the flagella and vacuoles are present in the dorsal region of the trophozoite. Scattered in the cytoplasm, we have noticed cytoplasmic clefts without being enveloped by membrane's, with a litule dense homogeneous content (Fig. 1), glycoger and tree ribosomes. Two marallet rows of microtubules ffunis) accompany the iniracyioplasmie track of the caudal flagella. The median body is fonned by microtubules wi thout apparent relationship to other structures. Mitochondria, endoplasmic reticulum and Golgi apparatus are not noticed

We have not observed differences between Giardia duodenalis group from hamsters and domestic rats or among Giardia muris group from hamsters, domestic rats and mice. Differences were, however, evidenced in the morphology of the ventro-lateral flange of trophozoites of Giardia muris and Giardia duodenalis groups.

In the two groups studied the flange is arranged peripherally to the striated disk presenting a eytoplasmic lin supported by marginal plates which are associated with one of the axonemes of the antero-lateral flagella.

In the Giardia duodenalis group both from hamsters (Fig. 2) and from domestic rats (F!g. 3 ), the cytoplasmic lip that makes up the ventrolateral flange is short and thick, and does not show electron dense material in its distal extremity. The plates that support the flange are striated, little developed and are just associated with the plasmic membrane of the ventral surface of the ventro-lateral flange. In this group. the osmiophilic lamella is not observed.

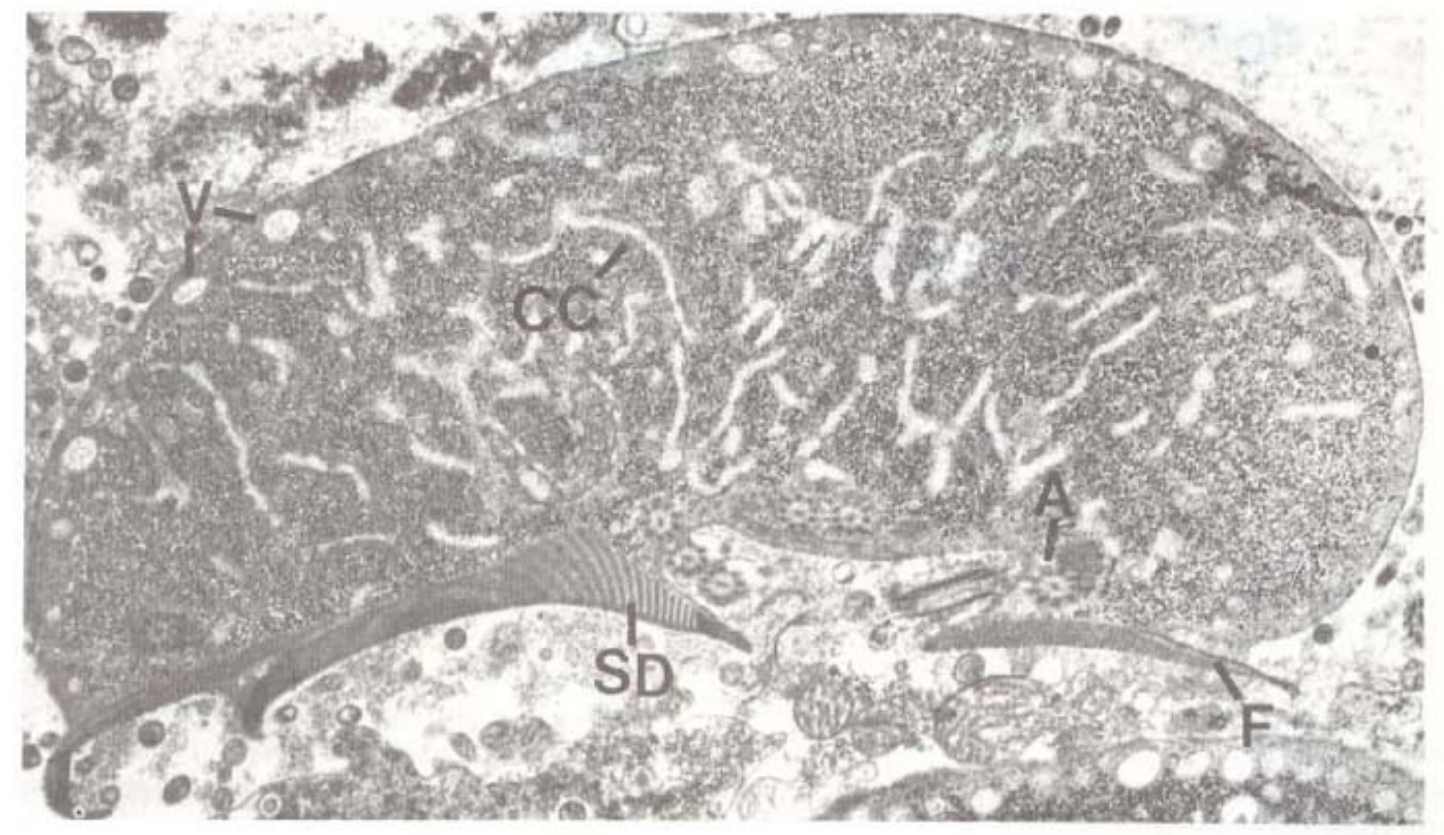

Fig. I - Giardia muris trophozoite from hamster. General aspect. Cross section showing vacuoles (V), cytoplasmic clefts (CC), striated disk (SD) and ventro-lateral flange (F). Axonemes of the flagella (A). X 15,500. 
SOGAYAR, M.I.1. \& (iREGORIO, L.A. - Giardia muris and Giardia duodenalis groups: ultrastructural differences between the (rophio/oites. Rev. Inst. Med. trop. S. Paulo, 31(4):242-247, 1989.

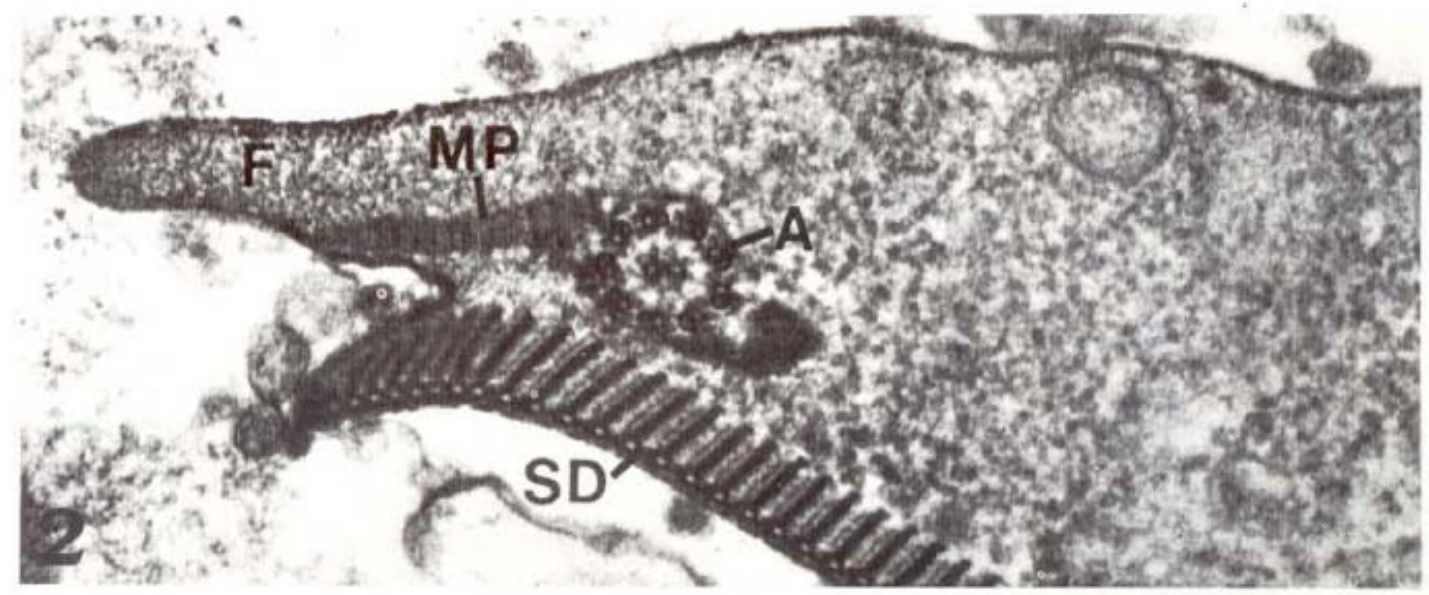

Fig. 2 - Giardia duodenalis trophozoite from hamster in eross-section. The ventro-lateral flange (F) is short and thick. Tie marginal plate (MP) is poorly developed, does not penetrate its extremity and is not accompanied by an electron-dense lamella. The axoneme (A) of the anterolateral flagella with adjacent osmiophilic material and the striated disk (SD) are shown. $\times 72,000$.

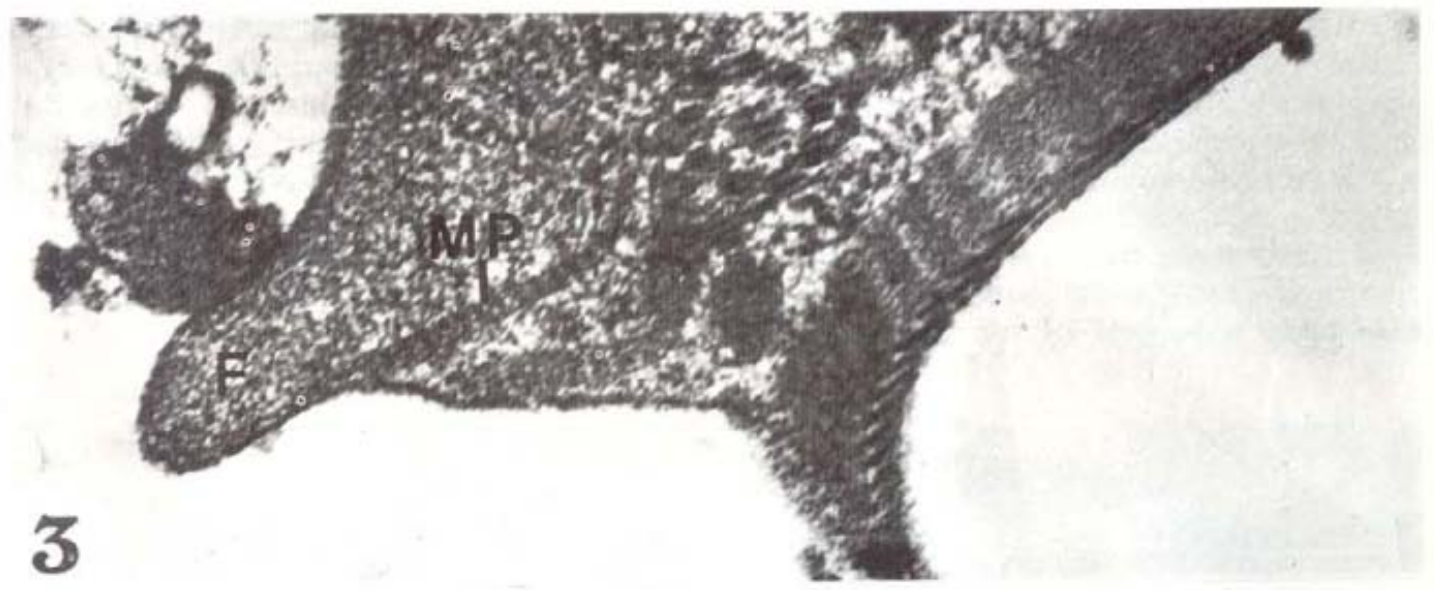

Fig, 3 - Giardia duodenalis trophozoite from domestic rat in tangential section. The ventro-lateral flange (F) and its marginal plate (MP) show the same morphological aspects as G. duodenalis trophozoites from the hamster. X 65,000 .

In Giardia muris group from hamsters (Fig. 4), domestic rats (Fig. 5) and mice (Fig. 6) the distal extremity of the cytoplasmic lip is narrow and developed, and it is darkened by dense cytoplasm. The marginal plates seem to occupy the whole flange extension. They extenci from the dorso-lateral surface of the striated disk into the ventro-lateral flange being

associated with the flange plasmic membrane either dorsally or ventrally. These marginal plates show striations and penetrate through the flange and become lost in the dense material of their distal extremity. A dense lamella of osmiophilic material that accompanies the dorsal surface of the plate is noticed associated with the marginal plates.

\section{DISCUSSION}

Giardia muris and Giardia duodenalis groups from hamsters and domestic rats, described for the first time in this paper, show a basic ultrastructural similarities to the other species already described in the literature, such as Giardia muris from mice $2.5,6,7.14$; Giardia lamblia from man 1,10,15; Giardia duodenalis from rabbits ${ }^{3}$ and Giardia canis from dogs ${ }^{13}$. 
SOGAYAR, M.I.L. \& GREGÓRIO, E.A. - Giardia muris and Giardia duodenalis groups: ultrastructural differences between the trophozoites. Rev. Inst. Med. trop. S. Paulo, 31(4):242-247, 1989.

Our results show that Giardia belonging to the same group (duodenalis or muris groups) do not present ultrastructural differences when located in different animals (hamsters-domestic rats and hamsters-domestic rats-mice, respectively).

However, Giardia belonging to different groups (muris and duodenalis) from the same host (hamster or domestic rat) show marked differences in the ventro-lateral flange ultrastructure regarding their size, arrangement of the marginal plates and presence of osmiophilic lamella.

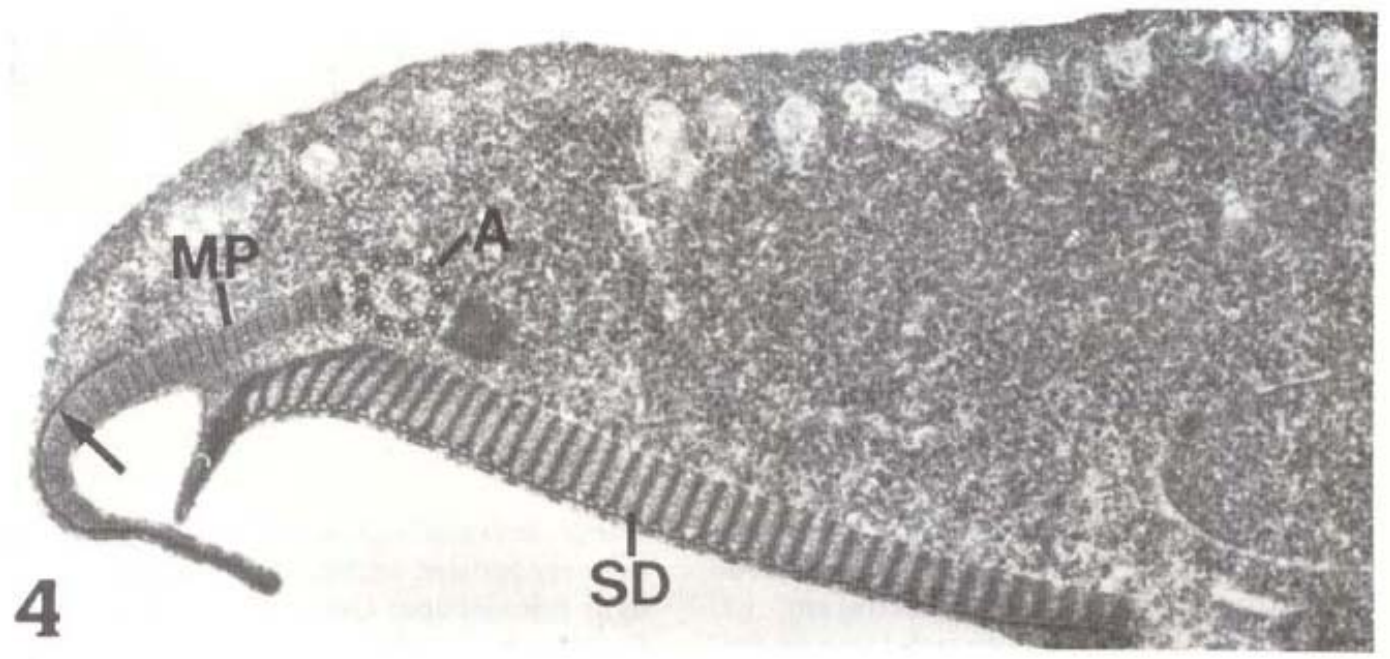

1.ig. 4-Giardia muris trophozoite from the hamster in cross-section. The ventro-lateral flange is long and narrow and the marginal plate (MP) penetrates through the distal extrenity of the flange. A lamella of electron-dense material (arrow) accompanies the dorsal surface of the marginal plate. The siriated disk (SD) and the axoneme of antero-lateral flagella (A) with adjacente osmiophilic material area show11. X 46,500.

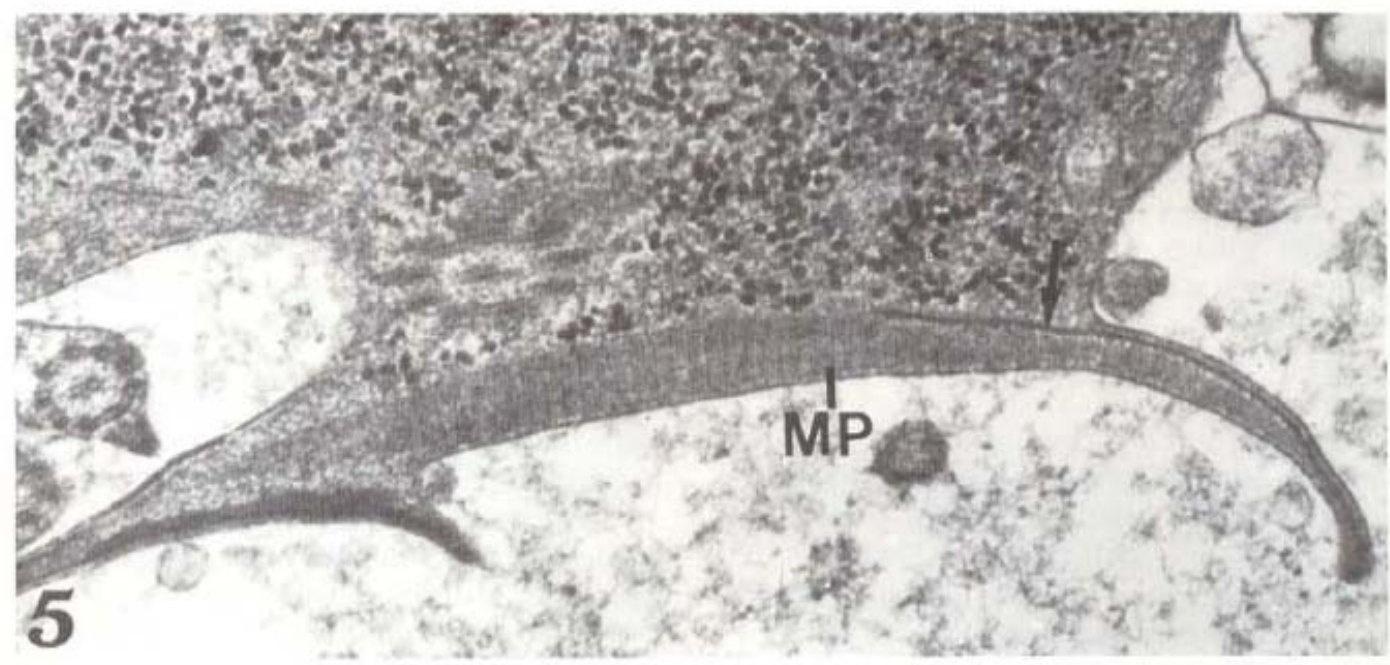

Fig. 5 - Giardia muris trophozoiles from domestic rat in cross-section. The ultrasiructure of the ventro-lateral flange (F). marginal plate (MP) and the osmiophilic lamella (arrow) is similar to those from Giardia muris from the hamster and mouse. $\times 46,200$. 
SOGAYAR, M.I.L. \& GREGÓRIO, E.A. - Giardia muris and Giardia duodenalis groups: ultrastructural differences between the trophozoites. Rev. Inst. Med. trop. S. Paulo, 31(4):242-247, 1989.

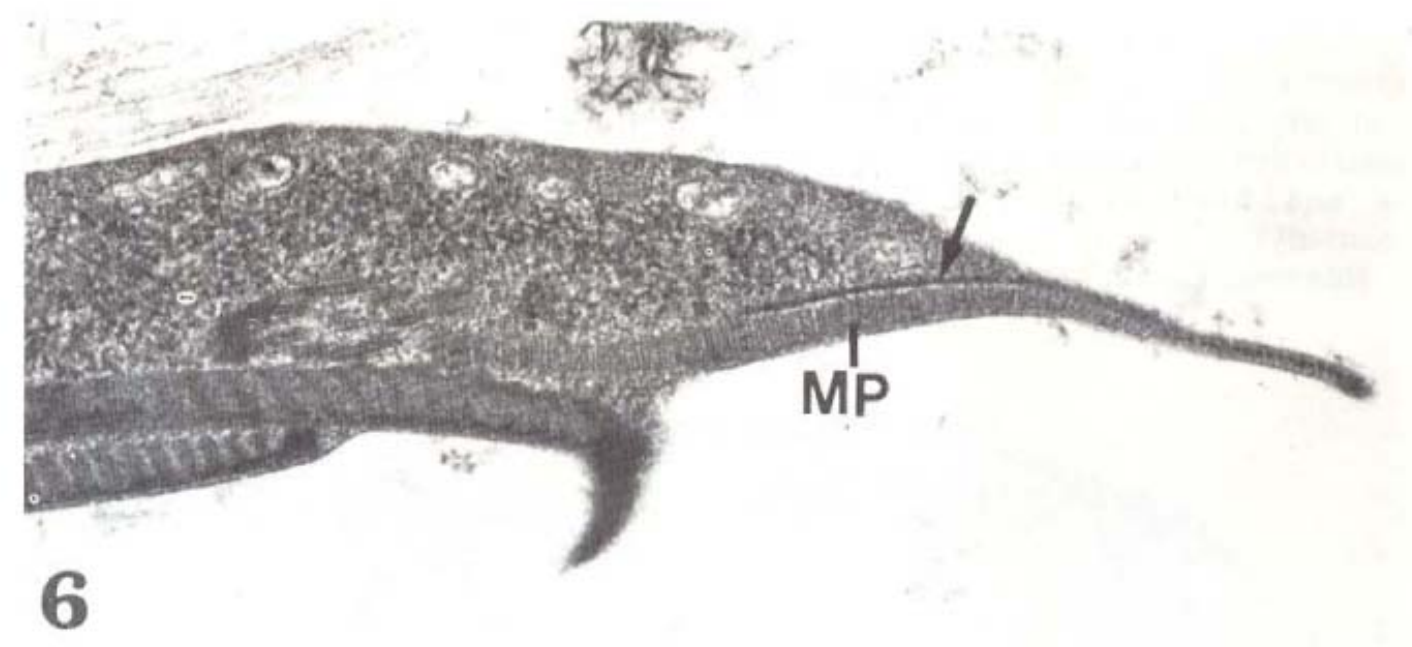

Fig. 6 - Giardia muris trophozoites from the mouse in cross-section, showing the ventro-lateral flange (F), marginal plate (MP) and osmiophilic lamella (arrow). X 72,000.

According to HOLBERTON 7 , it seems that the form adopted by the ventro-lateral flange may act on the attachment or detachment of the host to the substrate as the magnitude of the suction force caused by the striated disk depends on the caliber of the lateral channels between the ventro-lateral flange and the substrate. Therefore, the differences found between muris and duodenalis groups in relation to the ventro-lateral flange suggest that there is some difference in the attachment of these species to the substrate. The fact that the flange is less developed in Giardia duodenalis leads us to believe that it is not probable to have the fermation of lateral channels in this group. This would lead the species of Giardia duodenalis group to attach weakly to the substrate. Such a fact could explain the lack of any mirror-image attachment of the striated disk to the intestine in cases of human biopsies"1.

Previous publications did not provide evidence of ultrastructural differences between Giardia muris and Giardia lamblia trophozoites'2, although KULDA \& NORÝNKOVÁ ${ }^{x}$ in a review about Giardia ultrastructure, have suggested that the marginal plates in Giardia intestinalis are less developed than in Giardia muris.

It is well known that the taxonomy of the Giardia species is still somewhat controversial.
Three morphological different groups have been recognized among the species described by light microscope: Giardia agilis group which is found in amphibians, Giardia muris and Giardia duodenalis groups, which are found in mammals, each having a number of species" FILICE ${ }^{4}$ defined these groups as species but according to KULDA \& NORYNKOVA 8 they apparently represent higher tax.

The ultrastructural differences between Giardia muris and Giardia duodenalis groups and the similarities within each group of Giardia, shown in this paper, confirm this general tendency that point to the recognition of two morphological groups of Giardia in mammals. Although we do not know if these ultrastructural differences have some significance at the level of species, we can use the morphological feature of the ventro-lateral flange as an auxiliaire morphological character to help a differential diagnosis among groups of Giardia in favorable sections examined with electron microscope, even if the host is infected by more than one type of Giardia.

The axenic culture of Giardia duodenalis group obtained in laboratory have permitted the use of other methods besides those morphological features to study differences or similarities among isolates of Giardia from different animal species. However, these results have not yet been used to systematize Giardia species". 
SOGAYAR, M.1.L. \& GREGÓRIO, E.A. - Giardia muris and Giardia duodenalis groups: ultrastructural differences between the trophozoites. Rev. Inst. Med. trop. S. Paulo, 31(4):242-247, 1989.

\section{RESUMO}

Giardia muris e Giardia duodenalis: diferenças ultraestruturais entre trofozoitos

Neste trabalho foi analisada, através de Microscopia Eletrônica de Transmissão, a morfologia de trofozoitos de Giardia muris obtidos de hamsters, ralos peridomiciliares e camundongos, bem como de trofozoitos de Giardia duodenalis obtidos de hamsters e ratos peridomiciliares. Basicamente a ultraestrutura dos trofozoitos estudados foi semelhante. Foram observadas, no entanto, diferenças na morfologia da franja ventro-lateral dos trofozoitos de Giardia muris quando comparados com os de Giardia duodenalis, diferenças estas relacionadas ao tamanho, arranjo das lâminas marginais e presença de lamela osmiofílica.

\section{ACKNOWLEDGMENTS}

This work was supported by a Grant from the Conselho Nacional de Desenvolvimento Científico e Tecnológico (CNPq, Proc. n . 403177/82) and Fundação de Amparo à Pesquisa do Estado de São Paulo (FAPESP, Proc. n. 83/1428-7). The authors are indebted to Prof. Fernando Motta de Azevedo Corrêa for revision of the manuscript and to Maria Aparecida M. Ramos and Nivalde A. Basso for technical assistance.

\section{REFERENCES}

1. BARBIERI, D.; DE BRITO, T.; HOSHIDO, O.; NASCIMENTO F:, O.B.; MARTINS CAMPOS, J.V.; QUARENTEI, G. \& MARCONDES, E. - Giardiasis in childhood. Absorption tests and biochemistry, histochemistry, light and electron microscopy of jejunal mucosa. Arch. Dis. Childh., 45:466-472, 1970.
2. BRUGEROLle, G. - Contribution a l'étude cytologique et phylétique des diplozoaires (Zoomastigophorea, Diplozoa Dangeard, 1910). V. Nouvelle interprétation de l'organisation cellulaire de Giardia. Protistologica, 11:99-109, 1975.

3. CHEISSIN, E.M. - Ultrastructure of Lamblia duodenalis. I. Body surface, sucking disc and median bodies. J. Protozool., 11:91-98, 1965.

4. FILICE, F.P. - - Studies on the cytology and life history of a Giardia from the laboratory rat. Univ. Calif. Publ. Zool., 57:53-146, 1952.

5. FRIEND, D.S. - The fine structure of Giardia muris. J. Cell Biol., 29:317-331, 1966.

6. HOLBERTON, D.V. - Fine structure of the ventral disk apparatus and the mechanism of attachment in the flagellate Giardia muris. J. Cell Biol., 13:11-41, 1973.

7. HOLBERTON, D.V. - Attachment of Giardia, a hidrodynamic model based on flagellar activity. J. Cell. Sci., 60:207-221, 1974.

8. KULDA, J. \& NORÝNKOVÁ, E. - Giardia and Giardiasis. In: KREIER, J.P., ed. - Parasitic Protozoa. New York, Academic Press, 1978. vol. 2, p.69-138.

9. MEYER, E.A. - The epidemiology of giardiasis. Parasit. today, 1:101-105, 1985.

10. MORECKI, R. \& PARKER, J.C. - Ultrastructural studies of the human Giardia lamblia and subjacent jejunal mucosa in a subject with steatorrhea. Gastroenterology, 52:151-164, 1967.

11. MUELLER, J.C.; JONES, A.L. \& BRANDBORG, L.L. - SEM observations in human giardiasis. In: JOHARI, O., ed. - Scanning electron microscopy. Chicago, IIT Research Institute, 1973. p.557-564.

12. NEMANIC, P.C.; OWEN, R.L.; STEVENS, D.P. \& MUELLER, J.C. - Ultrastructure observations on giardiasis in a mouse model. II. Endosymbiosis and organelle distribution in Giardia muris and Giardia lamblia. J. infect. Dis., 140:222-228, 1979.

13. SOGAYAR, M.I.T.L. \& GREGORIO, E.A. - Ultrastructure of Giardia canis trophozoites. Zbl. Vet.-Med. B., 31:107-114, 1984.

14. SOLOVIEV, M.M. \& CHENTSOV, J.S. - Electron microscope study of Lamblia muris with regard to peculiarities of the ecology of the parasite. Med. Parazit. (Mosk.), 35:667-672, 1966.

15. TAKANO, J.\& YARDLEY, J.H. - Jejunal lesions in patients with giardiasis and malabsorption. An electron microscopy study. Bunf. Johns Hopk. Hosp., 116:413$429,1965$.

Recebido para publicação em 17/2/1989. 